\title{
Chromosomal aberrations and nucleic acids systems affected by some Egyptian medicinal plants used in treating female pregnant diabetic rats
}

\author{
Halima S. Abdou ${ }^{1}$, Sherifa H. Salah ${ }^{1 *}$, Amira Abd El Raouf ${ }^{1}$, Emam A. Abdel-Rahim ${ }^{2}$
}

${ }^{1}$ Department of Cell Biology, National Research Center, Dokki, Egypt;

${ }^{2}$ Department of Biochemistry, Faculty of Agriculture, Cairo University, Giza, Egypt.

Email: ahmedamm33@yahoo.com

Received 21 March 2011; revised 26 March 2011; accepted 28 March 2011.

\section{ABSTRACT}

The influences of medicinal plants Juniperus Phoenicea (Araar), Hyphaene thebaica (Doum), Anastatica hierochuntica (Kafta) and Cleome droserifolia (Sammo) as antidiabetic agents were investigated using female pregnant albino rats. Female rats were injected with $60 \mathrm{mg} / \mathrm{kg} \mathrm{b}$.w. alloxan to induce diabetes. Diabetic rats treated orally with the methanol extracts of tested plants till the 19 day of gestation. The present studies include the frequencies of chromosomal aberrations and nucleic acid system of liver in the female pregnant rats and their embryos. The results showed that injection of alloxan caused highly significant increase in chromosomal aberrations as well as in blood glucose levels as a result of diabetes in pregnant females. It also caused a high incidence of chromosomal deviation in embryos and decreased the liver soluble protein contents of female rats and their embryos. These effects in alloxanized animals were treated and improved by ingestion of the methanol extracts of the tested plants (Araar, Doum, Kafta and Somma) in which under their treatments, the inceased level of blood glucose of diabetic rats was deceased. Ingestion with the plants methanolic extracts improved and normalized the effects of diabetes in nucleic acids values of liver tissues. These were accompanied with nucleases (RNAase and DNAase) activities. The inhibited activities of both DNA ase and RNA ase of pregnant rats and their embryos were stimulated and readjusted around the normal values. Also administration of the plants methanol extracts decreased the percentage of chromosomal aberrations in the female rats and embryos. It is concluded that there are some biochemical dynamics which might occur in the metabolism of glucose, nucleic acids and proteins in order to prevent or to reduce the oxidative stress of diabetes by flavonoides treatment.

Keywords: Tested Plants: Cleome Droserfolia (Sommo); Jumiperus Phoenicia (Araar); Anostatica Hierochuntica (Kafta) and Hyphened Thebaica (Doum); Alloxan; Pregnant Females Albino Rats; Diabetes Mellitus

\section{INTRODUCTION}

Diabetes mellitus has become one of the most frequent complications-accompanying chronic diseases with high morbidity and mortality [1]. It is a metabolic disorder characterized by hyperglycemia resulting from lack of insulin, lack of insulin effect, or both. Two types of diabetes are recognized; type 1, known as insulin-dependent diabetes (IDDM), and type II, known as non-insulin-dependent diabetes (NIDDM) [2]. In type I diabetes, the absolute deficiency of insulin attributed to $\beta$-cell dysfunction leads to hyperglycemia, enhanced lipolysis, protein catabolism and ketosis [2]. Type II diabetes impairs the ability of insulin to stimulate both muscle glucose uptake and splanchnic glucose uptake, thus contributes to induce hyperglycemia [3]. The severity and frequency of the late degenerative complications are high in patients with either type I or type II diabetes mellitus [4].

The available methods for treatment of diabetes mellitus include diet or diet and oral hypoglycemic drugs or diet and insulin [5]. In traditional practices, medicinal plants are used to control diabetes mellitus in many countries. This caused an increase in the number of experimental and clinical investigations directed toward the validation of the hypoglycemic [6] and/or anti-diabetic [7] properties of different medicinal plants. It has been reported that the chard (Beta Vulgaris L.var. cicla) extract increased pancreatic beta cells in Streptozotocin (STZ)-diabetic rats [8]. Water extract of smallantus Sonchifolius (yacon) leaves fed to normal and STZ dia- 
betic rats also showed hypoglycemic effects [9]. Moreover, a long-term administration of olive leaves or Cinnamon bark caused significant improvement in tissue injury induced by STZ treatment [10]. The water extract of Anastatica hierochuntica, in the dose given and rout of administration used by Tarek and Mamdouh [11] has hypoglycemic effect in both normoglycemic and diabetic rats.

The objectives of the present study are to evaluate the hypoglycemic effect of the methanolic extracts of $J$. phoencea, $H$. thebaica, A. hierochuntica and Cleome droserifolia in normal and Alloxan-diabetic pregnant female rats and their embryos.

\section{MATERIAL AND METHODS}

\subsection{Animals}

Adult diabetic and normal albino rats (72 rats) weighing (120 - $150 \mathrm{~g})$ were maintained in a well ventilated animal house. Animals were housed in large spacious polypropylene cages with free access to food and ad libitum during the course of experiment [12]. Males and diabetic females were orally administered with the different treatments once daily, for one week, then two females were housed with one male overnight, and successful mating was confirmed by vaginal plug. The presence of vaginal plug was considered as the zero gestational day. The pregnant female's administration with the different treatments continuous during pregnancy till the $19^{\text {th }}$ day of gestation.

\subsection{Chemicals}

Alloxan: recrystallized, used to produce insulin-dependent diabetes experimentally.

\subsection{Experiments}

Pregnant females albino rats were divided into six groups (36 rats) Group I control group (normal pregnant females) was orally administered with distilled water, Group 2 animals were injected with alloxan $60 \mathrm{mg} / \mathrm{kg}$ [13] for only one injection and orally administered with distilled water (pregnant diabetic control), Group 3 pregnant diabetic rats were administered orally with 150 $\mathrm{mg} / \mathrm{kg}$ /day with methanolic extract of sammo, Group $4 \mathrm{p}$ pregnant diabetic rats administered orally with 150 $\mathrm{mg} / \mathrm{kg} /$ day with methanolic extract of kafta,group 5 pregnant diabetic rats administered orally with 150 $\mathrm{mg} / \mathrm{kg} /$ day with methanolic extract of araar and group 6 pregnant diabetic rats administered orally with 150 $\mathrm{mg} / \mathrm{kg} /$ day with methanolic extract of doum. Another six groups (36 rats) of nonpregnant females albino rats were used as controls for previous six groups, respectively for blood glucose values comparison.

Females were sacrificed at day $19^{\text {th }}$ of gestation and the chromosomes prepared from bone marrow cells of mothers according to Yosida and Amano [14]. In case of embryo, cells were prepared according to the method of Romagnano et al. [15] to study any genotoxic effect. For biochemical studies blood and livers of the females and their embryos were collected. Livers chilled up for analysis and blood plasma was prepared by centrifugation at $3000 \mathrm{rpm}$ and chilled up for analysis [16].

\subsection{Slide Preparation}

To study the chromosomal aberrations in bone marrow cells of females (mothers), 50 metaphases from each animal were examined. In the case of embryo cells, chromosomal aberrations of liver in 900 cells per each group were examined.

Determination of blood glucose was adopted using the method of Trinder [17]. Liver tissues were homogenized by the method of Peares [18] for determination of RNA and DNA. The DNA concentrations were determined in the supernatant according to Dische method [19] using diphenylamine reaction which produced blue color when heated with DNA. The RNA concentrations were determined using oricinol method according to Schneider method [20]. Total soluble protein in liver was determined according to Lowary et al. [21] method. The activity of liver nucleases was determined according to Bergmeger [22].

\subsection{Data Analysis}

Intergroup differences of cytogenetic and biochemical studies were analyzed statistically by using standard T-test according to Sokall and Rohlf [23].

\section{RESULTS}

\subsection{Cytogenetic Results}

The present result in Table 1 showed the frequencies of structural and numerical chromosomal aberrations as well as the mitotic activity induced by alloxan and also the effect of administration of the methanol extracts of the plants studied in female bone marrow cells. Injection with alloxan increased the frequencies of individual and total chromosomal aberrations in female bone marrow cells when compared with the control. This increase was found to be statistically significant at $(P<0.001)$.

Administration of the plants methanol extracts under test after injection with alloxan indicated that these plants methanol extracts significantly decreased the frequencies of chromosomal aberrations induced by alloxan $(P<0.001, P<0.01)$, but still higher than that of the normal pregnant control significantly.

Methanol extract of $H$. thebaica (Doum) ingestion showed the lowest percentage of total structural aberrations in female bone marrow cells when compared with those of Sammo, Araar and Kafra methanol extracts ingestion. Numerical aberrations also showed a significant 
Table 1. Chromosomal aberrations in the bone marrow of female rats treated with Sammo, Araar, Kafta and Doum after injection with alloxan.

\begin{tabular}{|c|c|c|c|c|c|c|c|c|c|c|c|c|c|c|}
\hline \multirow{3}{*}{ Groups } & \multirow{3}{*}{$\begin{array}{l}\text { Number } \\
\text { of } \\
\text { examined } \\
\text { cells }\end{array}$} & \multicolumn{8}{|c|}{ Structural chromosomal aberrations } & \multicolumn{3}{|c|}{ Numerical aberrations } & \multicolumn{2}{|c|}{$\begin{array}{c}\text { Mitotic in- } \\
\operatorname{dex}(\mathrm{MI})\end{array}$} \\
\hline & & \multirow{2}{*}{$\begin{array}{l}\text { Chromatid } \\
\text { gap }\end{array}$} & \multirow{2}{*}{$\begin{array}{l}\text { Chromo- } \\
\text { somal gap }\end{array}$} & \multirow{2}{*}{ break } & \multirow{2}{*}{ Fragment } & \multirow{2}{*}{ deletion } & \multirow{2}{*}{$\begin{array}{l}\text { endo- } \\
\text { mitosis }\end{array}$} & \multicolumn{2}{|c|}{ Total structural aberr. } & \multirow{2}{*}{$\begin{array}{l}\text { Hypo- } \\
\text { Ploidy }\end{array}$} & \multirow{2}{*}{$\begin{array}{l}\text { Hy- } \\
\text { per- } \\
\text { Ploidy }\end{array}$} & \multirow{2}{*}{$\begin{array}{c}\text { Total } \\
\text { Mean } \pm \text { S.E }\end{array}$} & \multirow{2}{*}{$\begin{array}{c}\text { No.of } \\
\text { exam- } \\
\text { ined } \\
\text { cells }\end{array}$} & \multirow{2}{*}{$\%$} \\
\hline & & & & & & & & $\%$ & Mean \pm S.E & & & & & \\
\hline Control & 250 & $1.2 \%$ & $0.0 \%$ & $0.0 \%$ & $0.0 \%$ & $0.4 \%$ & $0.0 \%$ & 1.6 & $0.666 \pm 0.449$ & $0.4 \%$ & $0.4 \%$ & $1.0 \pm 0.00$ & 10000 & 5.9 \\
\hline Alloxan & 250 & $6.8 \%$ & $3.6 \%$ & $2.0 \%$ & $1.2 \%$ & $7.6 \%$ & $6.0 \%$ & 27.2 & $11.3 \pm 1.056^{* * *}$ & $6.4 \%$ & $3.6 \%$ & $12.5 \pm 1.573^{* * *}$ & 10000 & $\begin{array}{c}3.7 \\
5\end{array}$ \\
\hline $\begin{array}{c}\text { Sammo + } \\
\text { Alloxan }\end{array}$ & 250 & $3.6 \%$ & $0.8 \%$ & $0.4 \%$ & $0.0 \%$ & $4.4 \%$ & $3.6 \%$ & 12.8 & $5.33 \pm 0.898^{* * *}$ & $4.8 \%$ & $2.4 \%$ & $9 \pm 1.456$ & 10000 & 5.3 \\
\hline $\begin{array}{l}\text { Araar + } \\
\text { Alloxan }\end{array}$ & 250 & $5.2 \%$ & $1.2 \%$ & $0.4 \%$ & $0.0 \%$ & $4.4 \%$ & $4.4 \%$ & 15.6 & $6.5 \pm 0.982^{* *}$ & $2.4 \%$ & $1.6 \%$ & $5 \pm 0.840$ & 10000 & 4.5 \\
\hline $\begin{array}{l}\text { Kafta }+ \\
\text { Alloxan }\end{array}$ & 250 & $4.4 \%$ & $0.8 \%$ & $0.8 \%$ & $0.8 \%$ & $5.2 \%$ & $4.8 \%$ & 16.8 & $7 \pm 0.958^{* *}$ & $4.4 \%$ & $2.8 \%$ & $9 \pm 1.189$ & 10000 & $\begin{array}{c}4.9 \\
2\end{array}$ \\
\hline $\begin{array}{l}\text { Doum }+ \\
\text { Alloxan }\end{array}$ & 250 & $2.8 \%$ & $2.0 \%$ & $0.8 \%$ & $0.0 \%$ & $4.0 \%$ & $2.4 \%$ & 12.0 & $5.0 \pm 0.772^{* * *}$ & $3.6 \%$ & $1.6 \%$ & $6.5 \pm 1.329^{*}$ & 10000 & 4.3 \\
\hline
\end{tabular}

* Significant at $\mathrm{P}<0.05, * *$ at $\mathrm{P}<0.01$ and $* * *$ at $\mathrm{P}<0.001$.

Table 2. Chromosomal aberrations in the embryos of female rats treated with Sammo Araar, Kafta and Doum after injection with alloxan.

\begin{tabular}{|c|c|c|c|c|c|c|c|c|c|c|c|c|c|c|c|}
\hline \multirow[b]{2}{*}{ Groups } & \multirow[b]{2}{*}{$\begin{array}{l}\text { No. of } \\
\text { embryos }\end{array}$} & \multirow[b]{2}{*}{$\begin{array}{l}\text { No.of } \\
\text { Cells. }\end{array}$} & \multicolumn{7}{|c|}{ Structural chromosomal aberration } & \multicolumn{4}{|c|}{ Numerical aberration } & \multicolumn{2}{|c|}{ Mitotic index } \\
\hline & & & break & C.A & del. & $\begin{array}{l}\text { Endo. } \\
\text { mitosis }\end{array}$ & gap & \multicolumn{2}{|c|}{$\begin{array}{c}\text { Total chromosomal } \\
\text { aberration exclud- } \\
\text { ing gap }\end{array}$} & \multicolumn{3}{|c|}{ hypo. } & hyper. & $\begin{array}{l}\text { No.of } \\
\text { cells }\end{array}$ & $\%$ \\
\hline Control & 15 & 900 & $0.44 \%$ & $1 \%$ & $0.33 \%$ & $0.56 \%$ & $1.1 \%$ & 2.33 & $5.25 \pm 1.518$ & 0.0 & $0.0 \pm 0.0$ & 0.0 & $0.0 \pm 0.0$ & 15000 & 17.2 \\
\hline Alloxan & 15 & 900 & $2.11 \%$ & $4 \%$ & $1.89 \%$ & $2.56 \%$ & $4.11 \%$ & 11.22 & $25.25 \pm 5.129^{* *}$ & 1.3 & $0.8 \pm 0.223$ & 1.1 & $0.67 \pm 0.252$ & 15000 & $9.1^{* * *}$ \\
\hline $\begin{array}{c}\text { Sammo + } \\
\text { alloxan }\end{array}$ & 15 & 900 & $0.78 \%$ & $1.4 \%$ & $1.1 \%$ & $0.89 \%$ & $1.4 \%$ & 3.52 & $7.5 \pm 1.513^{*}$ & 0.56 & $0.33 \pm 0.126$ & 6.33 & $0.2 \pm 0.107$ & 15000 & $15.5^{* * *}$ \\
\hline Araar + alloxan & 15 & 900 & $0.67 \%$ & $1.2 \%$ & $0.89 \%$ & $0.78 \%$ & $1.56 \%$ & 3.56 & $8 \pm 1.247^{* *}$ & 0.44 & $0.26 \pm 0.153$ & 0.33 & $0.2 \pm 0.107$ & 15000 & $15.5^{* * *}$ \\
\hline Kafta + alloxan & 15 & 900 & $0.56 \%$ & $0.56 \%$ & $0.78 \%$ & $1 \%$ & $1.3 \%$ & 3.44 & $7.75 \pm 1.28^{* *}$ & 0.22 & $0.13 \pm 0.091$ & 0.11 & $0.067 \pm 0.07^{*}$ & 15000 & $15.6^{* * *}$ \\
\hline $\begin{array}{c}\text { Doum }+ \\
\text { alloxan }\end{array}$ & 15 & 900 & $0.56 \%$ & $1.3 \%$ & $0.56 \%$ & $0.78 \%$ & $1.2 \%$ & 3.2 & $7.25 \pm 1.908^{* *}$ & 0.33 & $0.2 \pm 0.107$ & 0.22 & $0.13 \pm 0.091$ & 15000 & $15.5^{* * *}$ \\
\hline
\end{tabular}

decrease in animals injected with alloxan (diabetes) after treatment with methanolic extracts of the medicinal plants, but also still higher than the control. The mitotic activity increased after treatment with the extracts of the four plants to approximately reach the control group.

Table 2 showed that the results of structural and numerical chromosomal abnormalities in embryo cells of treated mothers in all experimental groups as well as the mitotic activity. The observed types of abnormalities were breaks, deletions, centromeric attenuations, endomitosis and gaps. Diabetic animals (alloxanized) showed a significant increase (at level of $P<0.01$ ) for total structural aberrations. The treatment with the methanolic extracts of the four tested plants inhibited the percentage of total aberrations significantly (at level of $P$ $<0.01$ ) although this percentage of abnormalities in treated groups remain significantly increased than the normal control group. Numerical aberrations were recorded and the results showed slight deviation from the normal group. The mitotic activity showed highly significant decrease $(P<0.001)$ after injection with alloxan (diabetes). Treatment with the plants extract increased the number of divided cells significantly to be near the normal group. The statistical analysis showed no significant difference between animals treated with different methanalic extracts of the medicinal plants.

\subsection{Biochemical Results}

The influences of Araar, Doum, Kafta and Sammo as hypoglycemic or antidiabetic agents were studied using their methanol extracts against alloxanized diabetes of female pregnant albino rats. The results in Table $\mathbf{3}$ summarized the blood glucose levels of the present experimental female normal and pregnant albino rats. The average level of blood glucose of the alloxanized normal female diabetic rats raised from $80.80 \pm 2.25 \mathrm{mg} / \mathrm{dl}$ for normal female (healthy without pregnancy) to $379.40 \pm$ $14.72 \mathrm{mg} / \mathrm{dl}$ for normal female diabetic rats, but for female pregnant rats, the values were increased from 88.00 \pm 0.79 to $421.60 \pm 8.88$, respectively. These elevated blood glucose levels of diabetic normal female and pregnant female albino rats were greatly decreased to around 
Table 3. Effect of the experimental medicinal plants as antidiabetic agents on blood glucose of diabetic female albino rats.

\begin{tabular}{ccccc}
\hline \multirow{2}{*}{ Treatments } & \multicolumn{2}{c}{ Normal female } & \multicolumn{2}{c}{ Pregnant female } \\
\cline { 2 - 5 } & $\mathrm{mg} / 100 \mathrm{ml}$ & $\%$ & $\mathrm{mg} / 100 \mathrm{ml}$ & $\%$ \\
\hline Normal control & $80.80 \pm 2.25$ & 100 & $88.00 \pm 0.79$ & 100 \\
Diabetic control & $379.40 \pm$ & 470 & $421.60 \pm$ & 479 \\
& 14.72 & & 8.88 & \\
Araar & $86.0 \pm 2.15$ & 106 & $90.00 \pm 2.89$ & 102 \\
Sammo & $85.40 \pm 2.41$ & 106 & $89.40 \pm 1.79$ & 102 \\
Kafta & $85.80 \pm 2.63$ & 106 & $92.00 \pm 4.96$ & 105 \\
Doum & $86.40 \pm 1.79$ & 107 & $91.20 \pm 2.41$ & 104 \\
\hline
\end{tabular}

that of normal control of normal and pregnant female animals which were ranged from $106 \%$ to $107 \%$ and from 102 to $105 \%$, respectively to their controls by ingestion of the methanol extracts of the four tested medicinal plants. The variation between the effects of four different plants was insignificant.

Table 4 also showed that diabetes decreased liver total soluble protein of both pregnant females and their embryos. The decreased values were $71 \%$ and $80 \%$, respectively relative to the normal control of pregnant $(167.7 \pm$ $3.16 \mathrm{mg} / \mathrm{g})$ and embryo $(128.1 \pm 2.12 \mathrm{mg} / \mathrm{g})$ liver. But ingestion of the studied medicinal plants methanol extracts improved the lower values of diabetic animals and normalized them to around the normal levels which ranged between $102 \%$ and $105 \%$ for pregnant liver and from $101 \%$ to $102 \%$ for embryo relative to their normal control.

Concerning to nucleic acids metabolism, the contents of DNA and RNA (as shown in Table 5) in pregnant and embryo liver tissues of diabetic rats were decreased significantly relative to their normal control. The nucleic acid values of diabetic pregnant liver amounted $47 \%$ and $72 \%$ relative to normal pregnant control, respectively for DNA and RNA contents (the normal values of DNA was $0.403 \pm 0.017 \mathrm{mg} / \mathrm{g}$ and for RNA was $0.190 \pm 0.007$ $\mathrm{mg} / \mathrm{g}$ tissue). These abnormal levels of nucleic acids produced by diabetes were improved by the administration of methanolic extracts of Kafta, Sammo, Araar and Doum which contained flavonoid compounds. These four extracts ingestion into diabetic animals readjusted DNA and RNA content in range of $103 \%-106 \%$ and $103 \%-107 \%$, respectively relative to those of normal pregnant control. In case of embryo, the contents of liver DNA and RNA were $0.210 \pm 0.004$ and $0.157 \pm 0.007$ $\mathrm{mg} / \mathrm{g}$ tissue of normal control. Diabetes reduced these values to $70 \%$ and $79 \%$ respectively relative to normal control. The tested medicinal methanol extracts treatments improved these effects of diabetes and normalized the level values of DNA and RNA of $123 \%-126 \%$ and $101 \%-105 \%$ relative to those of normal control, respectively. It means that methanol extracts (or flavonoids extract) of the four studied medicinal plants normalized and treated the harmful effects of diabetes on nucleic
Table 4. Effect of the experimental medicinal plants as antidiabetic agents on liver soluble protein of diabetic female albino rats and their embryos.

\begin{tabular}{ccccc}
\hline \multirow{2}{*}{ Treatments } & \multicolumn{2}{c}{ Pregnant liver } & \multicolumn{2}{c}{ Embryo liver } \\
\cline { 2 - 5 } & $\mathrm{mg} / \mathrm{g}$ tissue & $\%$ & $\mathrm{Mg} / \mathrm{g}$ tissue & $\%$ \\
\hline Normal control & $167.70 \pm 3.16$ & 100 & $128.10 \pm 2.12$ & 100 \\
Diabetic control & $118.60 \pm 2.99$ & 71 & $102.10 \pm 2.00$ & 80 \\
Araar & $170.2 \pm 2.87$ & 103 & $129.10 \pm 1.94$ & 101 \\
Sammo & $171.11 \pm 3.21$ & 102 & $128.41 \pm 2.11$ & 102 \\
Kafta & $175.50 \pm 3.42$ & 105 & $130.20 \pm 1.95$ & 102 \\
Doum & $176.60 \pm 3.33$ & 105 & $130.7 \pm 1.96$ & 102 \\
\hline
\end{tabular}

Table 5. Effect of the experimental medicinal plants as antidiabetic agents on liver DNA and RNA content of diabetic female albino rats and their embryos.

\begin{tabular}{ccccc}
\hline & \multicolumn{2}{c}{ PNA } & & Embryo liver \\
Treatments & Pregnant liver & & \\
$\mathrm{mg} / \mathrm{g}$ tissue & $\%$ & $\mathrm{mg}$ g tissue & $\%$ \\
Normal control & $0.403 \pm 0.017$ & 100 & $0.210 \pm 0.004$ & 100 \\
Diabetic control & $0.190 \pm 0.014$ & 47 & $0.147 \pm 0.005$ & 70 \\
Araar & $0.432 \pm 0.004$ & 107 & $0.261 \pm 0.002$ & 124 \\
Sammo & $0.430 \pm 0.004$ & 107 & $0.263 \pm 0.003$ & 125 \\
Kafta & $0.434 \pm 0.004$ & 108 & $0.259 \pm 0.002$ & 123 \\
Doum & $0.429 \pm 0.006$ & 106 & $0.264 \pm 0.007$ & 126 \\
& RNA & & & \\
Normal control & $0.190 \pm 0.007$ & 100 & $0.157 \pm 0.007$ & 100 \\
Diabetic control & $0.137 \pm 0.004$ & 72 & $0.124 \pm 0.004$ & 79 \\
& & & & \\
Araar & $0.199 \pm 0.008$ & 105 & $0.158 \pm 0.002$ & 101 \\
& & & & \\
Sammo & $0.195 \pm 0.007$ & 103 & $0.159 \pm 0.005$ & 101 \\
Kafta & $0.202 \pm 0.005$ & 106 & $0.161 \pm 0.005$ & 105 \\
Doum & $0.204 \pm 0.004$ & 107 & $0.162 \pm 0.003$ & 103 \\
\hline
\end{tabular}

Table 6. Effect of the experimental medicinal plants as antidiabetic agents on liver nucleases activity of diabetic female albino rats and their embryos.

\begin{tabular}{|c|c|c|c|c|}
\hline \multirow{2}{*}{ Treatments } & \multicolumn{2}{|c|}{ Pregnant liver } & \multicolumn{2}{|c|}{ Embryo Liver } \\
\hline & $\mathrm{mg} / \mathrm{g}$ tissue & $\%$ & $\mathrm{mg} / \mathrm{g}$ tissue & $\%$ \\
\hline \multicolumn{5}{|c|}{ DNAase } \\
\hline Normal control & $60.10 \pm 1.03$ & 100 & $58.32 \pm 1.01$ & 100 \\
\hline Diabetic control & $32.47 \pm 1.11$ & 54 & $30.11 \pm 0.63$ & 52 \\
\hline Araar & $61.12 \pm 2.16$ & 102 & $60.00 \pm 1.21$ & 103 \\
\hline Sammo & $62.12 \pm 1.97$ & 103 & $59.92 \pm 1.00$ & 103 \\
\hline Kafta & $62.00 \pm 2.42$ & 103 & $61.01 \pm 1.03$ & 105 \\
\hline Doum & $60.97 \pm 1.86$ & 101 & $60.11 \pm 0.98$ & 103 \\
\hline \multicolumn{5}{|c|}{ RNAase } \\
\hline Normal control & $36.24 \pm 0.65$ & 100 & $30.11 \pm 0.74$ & 100 \\
\hline Diabetic control & $20.22 \pm 0.50$ & 56 & $16.01 \pm 0.41$ & 53 \\
\hline Araar & $37.01 \pm 0.54$ & 102 & $31.00 \pm 0.23$ & 103 \\
\hline Sammo & $37.98 \pm 0.92$ & 105 & $31.11 \pm 0.72$ & 103 \\
\hline Kafta & $36.94 \pm 0.71$ & 102 & $30.87 \pm 0.53$ & 103 \\
\hline Doum & $37.00 \pm 0.83$ & 102 & $31.00 \pm 0.60$ & 103 \\
\hline
\end{tabular}

acid contents of diabetic pregnant female rats and their embryos.

The data presented in Table 6 showed that the activity of nucleases (DNAase and RNAase) of pregnant liver tissue and their embryo liver of diabetic animals which were inhibited significantly steadily when compared with those of normal pregnant healthy female control. The activity was inhibited to values ranged from $52 \%$ to $56 \%$ relative to those of normal control. It means that 
about half of the liver nucleases activity was lost by diabetes. The effects of diabetes oxidative stress on nucleases activity was improved and readjusted to around those of normal control by treatments of the methanol extracts of the present tested medicinal plants, in which the normalizedvalues were $101 \%$ - $103 \%$ and $103 \%$ $105 \%$, respectively for diabetic pregnant females and their embryo DNAase activity and 102\% - 105\% and $103 \%$, respectively for diabetes pregnant female and their embryo RNAase activity relative to those of normal pregnant healthy females and their embryos. The normal healthy pregnant control had values of $60.10 \pm 1.03$ $\mathrm{IU} / \mathrm{g}$ tissue and $58.32 \pm 0.01 \mathrm{IU} / \mathrm{g}$ tissues for DNAase activity and $36.24 \pm 0.65 \mathrm{IU} / \mathrm{g}$ tissue and $30.11 \pm 0.74$ $\mathrm{IU} / \mathrm{g}$ tissue for RNAase activity, respectively in pregnant females liver and their embryos.

The present results suggested that the treatment of diabetic pregnant females with the methanalic extrats of Araar, Doum, Kafta and Sammo which contain flavonoids compounds inhibited the induced chromosomal aberrations in the bone marrow cells and embryo cells and improved and readjusted the harmful and disturbed effects of diabetes on blood glucose and liver total soluble protein, RNA and DNA contents as well as liver nucleases (DNAase and RNAase) activity

\section{DISCUSION}

The increase in number of diabetic patients have motivated scientists to find new method to cure diabetes [1]. In the present study, the effect of the metabolic extracts of J. phoencea (Araar), H.thebaica (Doum), A. hierochuntica (kafta) and C. droserifolia (Sammo) were tested on normoglycemic as well as alloxan diabetic female pregnant rats and their embryos. The diabetogenic effect of alloxan and STZ was reported by several investigators $[1,24,25,26]$. It was indicated in the present study by the significant increase in blood glucose level in alloxan injected rats. It was also indicated by the highly significant increase in somatic chromosomal aberrations of pregnant female and their embryos. The effect of STZ and alloxan relate to their structure as a DNA alkylating agent, which leads to necrosis of pancreatic beta cells and thus to a state of insulin - dependent diabetes mellitus [27]. As alloxanized diabetes may either increase the entevance rate of glucase into blood from liver (stimulated hepatic glycogenolysis or gluconeogenesis) and may be reduced the rate of removal of glucose from blood by different tissues which decreased storage or utilization of glucose. These may be due to the absent of insulin. Alloxan acted directly promptly and specifically on the $\beta$-cells of pancreas [28].

On the other hand, the results indicated that administration of the methanol extracts of the present studied plants improved, but not completely normalized, the diabetogenic action induced by alloxan. They showed hypoglycemic effects on blood glucose level in plant treated diabetic females and embryos when compared with untreated diabetics. They also caused a significant decrease in the percentage of chromosomal aberrations caused by alloxan in both mothers and embryos. The four methanolic extracts had a great amount of flavonoid compounds which did not alter the low level of insulin [29].This means that the reducing effect of methanol extracts (flovonoid compunds) on blood glucose of diabetic animals was not related to the insulin content in blood. Flavonoids ingestien into diabetic animals increased blood adiponectin level, which produced a hypoglycemic action of insulin sensitivity [29,30,31,29]. Similarly, it is believed that the presence of flavone glycosidic components in the plant extract of Anastatia hierochuntia [32] is responsible for reducing the blood glucose level in STZ-diabetic rats. Such hypoglycemic effect could be through increased serum insulin levels provided by repair/ regeneration of the endocrine pancreas.

Results of liver total soluble protein nucleic acids and nucleases showed that diabetes caused a great harmful and disturbance in liver metabolism including either in liver metabolites content or in enzymes activity, but the medicinal plants methanol extracts (included falvonoids) improved and normalized these harmful and disturbed effects of diabetes on livers metabolism as well as their metabolites. The present results are in agreement with those of Salah et al. [33]. They found that flovonoids of the metabolic extracts of Kafta, Araar, Somma and Doum improved and treated diabetes in case of blood glucose, and liver contents of total soluble protein, RNA and DNA as well as the activity of enzymes related to nucleic acid such as nucleases (RNAase and DNAase). They also found that it inhibited the percentage of chromosomal aberrations in male somatic and germ cells.

It means that, the effects of diabetes oxidative stress on liver protein and nucleic acids as well as their nucleases activity was readjusted and improved by ingestion of alcoholic extracts of the four present medicinal plants.

On the other hand, there is no any available data was observed in literature about these items in pregnant animals and their embryo, except those of our work on male albino rats. The present findings of DNA content in liver of pregnant females and their embryos are confirmed by the results of chromosomal abberrations in which DNA content was deceased and chromosomal aberrations were increased by diabetes. Also, RNA content data confirmed the results of protein content which is in agreement with the findings of nucleases activity. This means that the present results confirmed each other. The results showed that plants methanol extracts (including flavon- 
oides) might cause an adaptation of certain enzymes system in the animal tissues of diabetic animals which provide the necessary enzymatic mechinary to cope with the increased flow of nucleotides during the experimental period by converting it rapidly into DNA and RNA (m-RNA, r-RNA and t-RNA). However, flavonoides may play a role in the improvement of replication and transcription enzymes activity to produce DNA and RNA. In addition, the efficiency of flavonoides against the oxidative stress of diabetes is not completely known $[29,34]$. Flavonoides were in conjugation with adiponectin may play a role in binding of insulin with its receptor. Moreover, these compounds may interfere with signal sequences of insulin inside the cell $[35,36]$. The induction of flavonoides extracts elevated the adiponectin levels in the diabetic rats, which showed glucose lowering effects and improvement in insulin resistance and sensitivity and diabetic oxidative stress as well as the whole body metabolism [36].

From the present results, it can be concluded that there are some biochemical dynamics which might occur in the metabolism of glucose, nucleic acids and proteins in order to prevent or to reduce the oxidative stress of diabetes by flavonoides treatment. The decrease of blood glucose with increase soluble protein and nucleic acids content as well as stimulation of nucleases activity of liver tissues in diabetic female pregnant rats and their embryos by flavonoides induction subsequently is considered as results of diabetes oxidative stress which was treated by flavonoides compounds. Also, the results suggested that, the stimulation of protein biosynthesis processes was marked by increase the RNA content as well as stimulation of nucleases activity. The enzymes may supply transcription stage of protein biosynthesis with the needed precursors nucleotides [37].

\section{REFERENCES}

[1] Adeghate, E. (1999) Effect of subcutaneous pancreatic tissue transplants on streptozotocin-induced diabetes in rats. II. Endocrine and metabolic functions. Tissue and Cell, 31, 73-83. doi:10.1054/tice.1999.0007

[2] Hansen, M. (1998) Pathophysiology: Foundations of disease and Clinical Intervention. 1st Edition, W.B. Saunders Company, Philadelphia, 851-852.

[3] Basu, A., Basu, R., Shah, P., Vella, A., Johnson, C.M., Nair, K.S., Jensen, M.D., Schwenk, W.F. and Rizza, R.A. (2000) Effects of type 2 diabetes on the ability of insulin and glucose to regulate splanchnic and muscle glucose metabolism: Evidence for a defect in hepatic glucokinase activity. Diabetes, 49, 272-283. doi:10.2337/diabetes.49.2.272

[4] Adeghate, E. (1999) Effect of subcutaneous pancreatic tissue transplants on streptozotocin-induced diabetes in rats. I. Morphological studies on normal, diabetic and transplanted pancreatic tissues. Tissue and cell, 31, 66-

\section{2. doi:10.1054/tice.1999.0008}

[5] Boon, N.A., Chilvers, E.R., Haslett, C. and Hunter, J.A. (1999) Davidson's Principles and Practice of Medicine. Churchill Livingstone, Edinburgh, pp 482-483.

[6] El-Ridi, M.R. (2001) A possible hypoglycemic effect of some medicinal plants used in united Arab emirates. Bulletin of the Egyptian Society of Physiology and Science, 21, 9-16.

[7] Alarcon-Aguilara, F.J., Ramon-Ramos, R., PerezGutierrez, S., Aguilar-Contreras, A., Contreras-Weber, C.C. and Flores-Saenz, J.L. (1998) Study of the antihyperglycemic effect of plants used as anti diabetics. Journal of Ethnopharmacology, 61, 101-110.

[8] Bolkent, S., Yanardag, R., Tabakoglu-Oguz, A. and Ozsoy-Sacan, O. (2000) Effect of chard (Beta vulgaris L. Var. Cicla) extract on pancreatic $\beta$ cells in streptozotocindiabetic rats: A morphological and biochemical study. Journal of Ethnopharmacology, 73, 251-259. doi:10.1016/S0378-8741(00)00328-7

[9] Aybar, M.J., Sanchez Riera, A.N., Grau, A. and Sanchez, S.S. (2001) Hypoglycemic effect of the water extract of smallantus sonchifolius (yacon) leaves in normal and diabetic rats. Journal of Ethnopharmacology, 74, 125132. doi:10.1016/S0378-8741(00)00351-2

[10] Onderoglu, S., Sozer, S., Erbil, K.M., Ortac, R. and Lermioglu, F. (1999) The evaluation of long-term effects of cinnamon bark and olive leaf on toxicity induced by streptozotocin administration to rats. Journal of Pharmacy and Pharmacology, 51, 1305-1312.

[11] Rahmy, T.R. and El-Ridi, M.R. (2002) Action of Anastatica hierochuntica plant extract on Islets of langerhans in normal and diabetic rats. Egyptian Journal of Biology, 4, 87-94.

[12] Lane-Petter, W. and Pearson, A. (1971) Dietary requires. In: The Laboratory Animal Principles and Practice, Academic Press, London and New York, 25-32.

[13] Lazaro, A. (1949) Alloxan and pathogenesis of diabetes mellitus. Physical Review, 29, 48-51.

[14] Yosida, T.H. and Amano, K. (1965) Autosomal polymorphism in laboratory bred and wild Norway rats Rattus norvegicus, found in Misima. Chromosoma, 16, 628-667. doi:10.1007/BF00285115

[15] Romagnano, A., King, A.W., Richer, C.L. and Perrone, M.A. (1985) A direct technique for the preparation of chromosomes from early enquine embryos. Canadian Journal of Genetics and Cytology, 27, 365-396.

[16] Astawrov, B.L. (1974) Methods in biochemical development. Nauka, Moscow, 336-339.

[17] Trinder, P. (1969) Enzymatic determination of glucose in blood serum. Annals of Clinical Biochemistry, 6, 24.

[18] Peares, A.G.E. (1985) Histochemistry: Theoretical applied. Volume two: Analytical technology. 4th Edition. Churchill Livingston, Philadelphia.

[19] Dische, Z. (1995) Color reaction of nucleic acid components. In: E., Chargaff and J.M. Davidoson, Eds., The Nucleic Acids, Academic Press, New York, 270-284.

[20] Schneider, W.C. (1957) Determination of acid in tissues by pentose analysis. In: Colowick, S.P. and Kaplan, N.O. Ed., Method Etymology, Academic Press, New York, 680-684.

[21] Lowary, O.H, Resabrought, N.J, Farr, A.L. and Randoll, 
R.J. (1951) Protein measurement with the folin phenol reagent. The Journal of Biological Chemistry, 193, 265275.

[22] Bergmeyer, U.H. (1974) Determination of nucleases activity (RNAase and DNAase). In: Method of Enzymatic Analysis (2nd Edition), Academic Press, New York, 447 and 511 .

[23] Sokall, R.R. and Rohlf, F.J. (1995) Biometry. W.H Freeman and Company, New York.

[24] Choi, J.S., Yokozawa, T. and Oura, H. (1991) Improvement of hyperglycemia and hyperlipemia in streptozotocin-diabetic rats by a methanolic extract of Prunus davidiana stems and its main component, prunin. Planta Medica, 57, 208-211. doi:10.1055/s-2006-960075

[25] Wang, T., Fontenot, R.D., Soni, M.G., Bucci, T.J. and Mehendale, H.M. (2000) Enhanced hepatotoxicity and toxic outcome of thioacetamide in sterptozotocin-induced diabetic rats. Toxicology and Applied Pharmacology, 166, 92-100. doi:10.1006/taap.2000.8952

[26] Bnouham, M., Mekhfi, H., Legssyer, A. and Ziyyat, A. (2002) Medicinal plants used in the treatment of diabetes in Morocco. International Journal of Diabetes and Metabolism, 10, 33-50.

[27] Elsner, M., Guldbakke, B., Tiedge, M., Munday, R. and Lenzen, S. (2000) Relative importance of transport and alkylation for pancreatic beta-cell toxicity of streptozotocin. Diabetologia, 43, 1528-1533. doi:10.1007/s001250051564

[28] Chatterjea, M.N. and Shinde, R (2002) Text book of medical biochemistry. 5th Edition, Jaypee Brothers, New Delhi.

[29] Ismail, S.A., Ahmed, S.H., Fayed, S.A. and Mohmoud, G.I. (2007) Adiponectin, insulin and nitric oxide levels in hyperlipidemia and hypercholesterolemia in addition of streprozotocin-induced diabetes mellitus and normal rats intraperitonially injected with anthocyanin and epicatechin extracts. New Egyptian Journal of Medicine, 36, 135-143.
[30] Combs, T.P., Wagner, J.A., Berger, J., Doebber, T., Wang, W., Zhang, B., Tanen, M., Berg, A., O'Rahilly, S., Savage, D., Chatterjee, R., Weiss, S., Larson, J., Gottesdiener, R., Gertz, B., Charron, M., Scherer, P. and Moller, D. (2002). Induction of adipocyte complement-related protein of $30 \mathrm{k} . d$. by PPAR $\gamma$ and agonists a potential mechanism of insulin sensitization. Endocrinology, 143, 9981007.

[31] Yamauchi, T., Kamon, J. and Ito, Y. (2003) Cloning of adiponectin receptors that mediate antidiabetic metabolic effects. Nature, 423, 762-679. doi:10.1038/nature01705

[32] Khalifa, T.I.M.A. (1980) A pharmacognostical study of certain species of anastatica. Ph.D. Thesis, Cairo University, Egypt.

[33] Salah, S.H., Abdou, H.S., Abd El-Azeem A.S.E. (2010) The antioxidative effects of some medicinal plants as hypoglycemic agents on chromosomal aberration and abnormal nucleic acids metabolism produced by diabetes stress in male adult albino rats. Journal of Diabetes Mellitus, 1, 6-14. doi:10.4236/idm.2011.11002

[34] Coskun, O., Kanter, M., Korkmaz, A. and Oter, S. (2005) Quercetin, a flavonoid antoixdant, prevents and protects streptozotocin induced oxidative stress and $\beta$-cell damage in rat pancreas. Pharmacological Research, 51, 117123. doi:10.1016/j.phrs.2004.06.002

[35] Anton, S., Melville, L. and Rena, G. (2007) Epigallocatachin gallate (EG. CG) mimiss insulin action on the transcription factor FOXOIa and elicits cellular responses in the presence and absence of insulin. Cellular Signaling, 19, 378-383. doi:10.1016/j.cellsig.2006.07.008

[36] Abdel-Magid, G.I.M. (2007) Biochemical studies on adiponectin. Ph.D.Thesis, Cairo Univiversity, Egypt.

[37] Adams, R.L.P., Knowler, J.T. and Leader, D.P. (1993) The biochemistry of nucleic acids. 11th Edition, Chepman and Hall Publishers, New York. 